\title{
日本脊檤外科学会 会員の皆様へ重要なお知らせ
}

\section{（1）「事務局」変更のお知らせ}

日本脊髄外科学会事務局はこれまで大阪市立大学脳神経外科内にあり, 白馬 明教授がご担当 されてこられましたが，第14回日本脊髄外科学会の際の世話人会にて，2000年 1 月 1 日より，私， 愛知医科大学脳神経外科, 中川 洋が担当することに決定致しました.

これに伴い私は，大学内に事務局を置いて事務作業を行うというこれまでの方式から，外部に 事務を委託する方式に変えて，事務に関わる経費の削減と明確化を計りたいと考えました。

このため，日本春髄外科学会事務局の事務的な仕事は下記にて行うことと致しました．会員の 皆様におかれましては, 入会, 退会, 休会, 住所変更等, 事務的なご連絡は愛知医科大学脳神経 外科ではなく，下記「分局」にご連絡くださいますようお願い申し上げます。私は日本春髄外科 学会事務局を担う責任者として, この「分局」の仕事を常時監督し, 事務経費の無駄を省き, 明 確化に努めると共に，会員の皆様にご迷惑のないよう，すみやかな事務作業の進行に努力する所 存です.

なお，この「分局」は，日本脊䯣外科学会機関誌「脊䯣外科」の編集制作業務を行っている 「編集室分室」でもございます。

日本脊䯣外科学会の今後益々の発展のため, 事務局業務を通じて少しでもお役に立てれば幸甚 に思います。

2000年1月

日本脊髄外科学会事務局 愛知医科大学脳神経外科 教授 中川 洋

記

日本脊髄外科学会事務局「分局」

担当：長瀬恵美子

有限会社EMINET

干 224-0036 横浜市都筑区勝田南 2-2 - 24-902

TEL : $045-592-8734$

FAX : $045-592-8759$

「分局」業務時間：月曜日〜金曜日 $9 ： 00 〜 17: 00$ （土，日，祝日は休みです.） 


\section{（2）「編集局」について}

日本春髄外科学会編集局は 2000 年からも変更はございません.これまでどおり北海道大学脳神 経外科内にあり，阿部 弘教授が編集委員長を担当します。

「脊髄外科」(Spinal Surgery) では一般の投稿論文を歓迎いたします。従来の論文の多くは， 日本脊髄外科学会の発表からの推薦論文が主でしたが, 今後は, 投稿論文を沢山揭載したいと考 えております。原著, 症例報告, 研究発表等, 様々な形式の論文を歓迎いたしますので, 日本 語・英語を問わず，積極的なご投稿をお待ちしています．ただし，他誌に類似の論文を投稿して いないようご配慮ください. 投稿の際に同封いただくフロッピーディスクは，必ずテキストファ イル形式でお送りくださいますようお願い申し上げます.

また，本誌に対するご意見，ご感想，アイデアなどもどしどしお寄せください. 投稿に関して は，日本脊髄外科学会「編集局」まで，いつでもご遠慮なくお問い合わせください.

干060-8638 札幌市北区北15条西7丁目 北海道大学医学部脳神経外科学講座内

「脊䯣外科」編集局

TEL : 011-716-1161（内線5987）

FAX : 011-706-7878

\section{（3）年会費の振り込みについて}

事務局の変更に伴い，会費の振込口座も変更になります。会員の皆様におかれましては，これ までの振込用紙は使用できませんので，宜しくお願い申し上げます.

なお，新しい郵便局の口座は下記のとおりです。

口座番号：00270-3-38342

口座名称：日本脊髄外科学会事務局 